Review

\title{
A Review of Sustainable Maintenance Strategies for Single Component and Multicomponent Equipment
}

\author{
Jingyi Zhao ${ }^{1,2, *(0)}$, Chunhai Gao ${ }^{2}$ and Tao Tang ${ }^{1}$ \\ 1 School of Electronic and Information Engineering, Beijing Jiaotong University, Beijing 100044, China; \\ ttang@bjtu.edu.cn \\ 2 Traffic Control Technology Co., Ltd., Beijing 100070, China; chunhai.gao@bj-tct.com \\ * Correspondence: netzhaojy@163.com; Tel.: +86-010-83606057
}

Citation: Zhao, J.; Gao, C.; Tang, T. A Review of Sustainable Maintenance Strategies for Single Component and Multicomponent Equipment. Sustainability 2022, 14, 2992. https:// doi.org/10.3390/su14052992

Academic Editor: Eleni Iacovidou

Received: 23 January 2022

Accepted: 1 March 2022

Published: 4 March 2022

Publisher's Note: MDPI stays neutral with regard to jurisdictional claims in published maps and institutional affiliations.

Copyright: (C) 2022 by the authors. Licensee MDPI, Basel, Switzerland. This article is an open access article distributed under the terms and conditions of the Creative Commons Attribution (CC BY) license (https:// creativecommons.org/licenses/by/ $4.0 /)$.

\begin{abstract}
Contemporary industrial equipment is increasingly developing towards complexity. In order to ensure the high reliability and sustainability of industrial equipment, more flexible maintenance strategies have attracted extensive attention. In view of this, this paper aims to summarize the current situation of existing maintenance strategies, so as to enable colleagues in the industry to choose or formulate more efficient maintenance strategies. Firstly, the characteristics, application potential and limitations of single component maintenance strategies, such as corrective maintenance, preventive maintenance and predictive maintenance, are described in detail from the perspective of maintenance time. On the basis of single component maintenance and the dependency between multiple components, the advantages and disadvantages of multicomponent maintenance strategies, such as batch maintenance, opportunity maintenance and group maintenance, are summarized, and suggestions for the future maintenance of industrial equipment are proposed. Based on this, industries can select the appropriate maintenance strategy according to their equipment characteristics, or improve their existing maintenance strategies based on actual needs.
\end{abstract}

Keywords: maintenance strategy; dependency; maintenance cost; multicomponent

\section{Introduction}

Maintenance refers to all technologies and management carried out to ensure that equipment performs or that restores its specified functions [1]. Maintenance plays an important role in the normal operation of industrial equipment, military equipment, transportation tools and other systems, as well as ensuring the safety and reliability of the system [2,3]. It is worth noting that enterprises in various countries spend a lot of money on maintenance. According to one survey, the maintenance cost of industrial equipment in China usually accounts for more than $15 \%$ of the total production cost [4]. American domestic enterprises spent nearly USD 600 billion repairing their key equipment in the 1980s, and that maintenance cost has doubled in the last 20 years [5]. The cost of industrial equipment maintenance in Germany accounts for $13 \%$ to $15 \%$ of its gross domestic product, while the cost of equipment maintenance in the Netherlands accounts for $14 \%$ of gross domestic product [6,7]. One third of such maintenance costs are wasted in the implementation of maintenance [8].

In order to improve the sustainable and reliable operation ability of industrial equipment, and reduce maintenance costs, researchers have proposed numerous and various maintenance methods since the 1940s $[9,10]$. The commonly used maintenance method in the early stage is corrective maintenance, which mainly arranges repair activities for failed equipment to restore its normal function [11]. This maintenance technology is driven by failure events [12]. It easily interrupts the normal work plan of the equipment, and it is prone to the problem of maintenance lag, caused by the untimely preparation of maintenance resources [13]. In view of the many disadvantages of corrective maintenance, preventive 
maintenance arranges maintenance activities for the same type of equipment before rapid operation has developed [14]. This maintenance method ignores the differences between individual pieces of equipment. For a single piece of equipment, it is prone to over or untimely maintenance [15]. Since the 1970s, the testing technology and information technology of various equipment have developed rapidly, and are now widely used. More and more research units have begun to focus on the application of predictive maintenance [16]. Such maintenance can formulate accurate maintenance measures in the future, according to the real time status information of the monitored equipment [17]. However, it is not applicable to dealing with maintenance decisions for monitoring restricted equipment. To sum up, various maintenance technologies have their own characteristics, applicability and limitations.

The basic idea of maintenance decision modeling for a certain type of equipment consists of several steps (Figure 1). First is to establish the equipment fault or deterioration model according to its structure and state characteristics $[18,19]$. Second is to establish the relationship between maintenance decision variables and optimization objectives according to the equipment maintenance strategy $[20,21]$. Third is to use a certain type of optimization method to obtain maintenance variables, such as maintenance time interval, inspection time interval, etc. [22,23]. In summary, maintenance strategies are an important part of maintenance decision modeling. The maintenance variables can be obtained only after the maintenance strategy is determined.

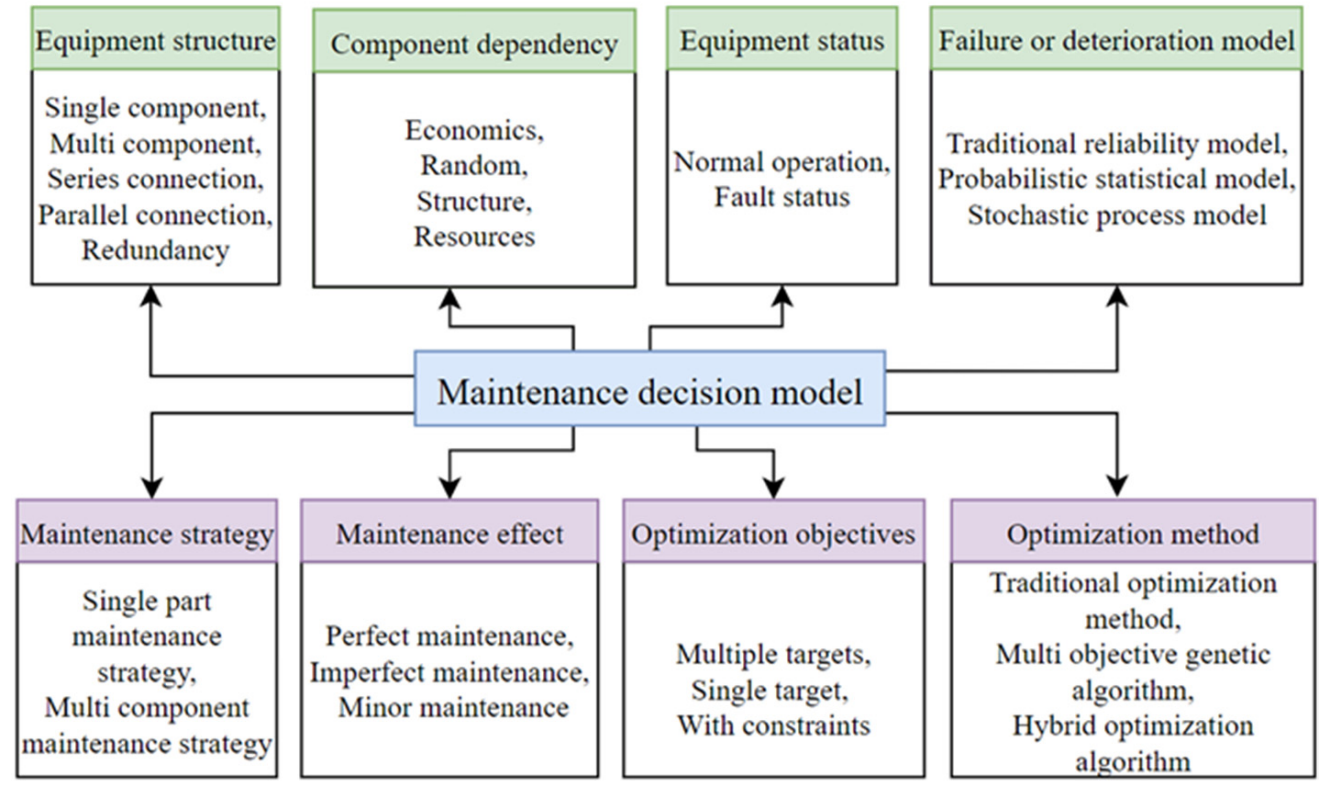

Figure 1. Composition of the maintenance decision model.

This paper aims to review the maintenance strategies used for industrial equipment. The remainder of this paper is organized as follows. Section 2 briefly presents the maintenance effect. Section 3 presents the influence of intra-equipment dependency on maintenance. Section 4 presents an overview of single component and multicomponent equipment maintenance strategies. Section 5 concludes, and provides some suggestions for the maintenance of industrial equipment in the future.

\section{The Maintenance Effect}

Maintenance mainly includes servicing and repair. Among them, servicing is the activity that maintains the stability of the equipment working state and prevents state degradation [24]. Actions such as cleaning, dust removal and lubrication are all servicing actions [25]. Repair is an activity undertaken after system failure. These failures can only be recovered by repair actions, such as replacing parts [26]. 
Each maintenance action has an impact on equipment degradation to certain degrees [27]. In order to accurately describe these impacts, scholars have proffered the concepts of perfect maintenance, imperfect maintenance and minor maintenance, as shown in Table 1. Among them, perfect maintenance refers to restoring equipment to its initial operation state [28]. For example, replacement is a kind of perfect maintenance and can make the repaired equipment as new, in a timely manner [29]. Early maintenance models basically adopted this type of maintenance method (i.e., replacement).

Table 1. Maintenance effect and characteristics.

\begin{tabular}{ccc}
\hline Name & Characteristic & Examples of Maintenance Actions \\
\hline Perfect maintenance & Equipment status is restored as new & Replace component \\
\hline Imperfect maintenance & $\begin{array}{c}\text { Equipment status is restored to between new } \\
\text { equipment and failed equipment }\end{array}$ & Repair failure location \\
\hline Minor maintenance & Equipment status returns to before the failure & Fastening component \\
\hline
\end{tabular}

In practice, equipment maintenance methods vary greatly. The maintenance process may be affected by human error, poor quality of spare parts, insufficient maintenance time and other factors, so that the equipment cannot be restored to a new state [30,31]. Based on this, researchers proposed maintenance concepts other than perfect maintenance, such as imperfect maintenance and minor maintenance [32]. Among them, the effect of imperfect maintenance lies between minor maintenance and perfect maintenance [33]. The failure rate of equipment after maintenance is reduced, but it is still higher than that of equipment in a new state [34]. The condition of the equipment is also worse than new but better than the failed equipment. The common imperfect maintenance forms in the literature includes medium maintenance, overhaul, etc. [35]. Researchers have put forward many methods to express the effect of imperfect maintenance, and the typical treatment methods are the virtual age method, impact model method and so on [36]. Minor repair refers to equipment being restored to the state before the fault, after maintenance, without being changed [37]. It is generally considered that a minor repair does not change the fault rate of the system [38]. The influence of various maintenance effects on the failure rate is shown in Figure 2.

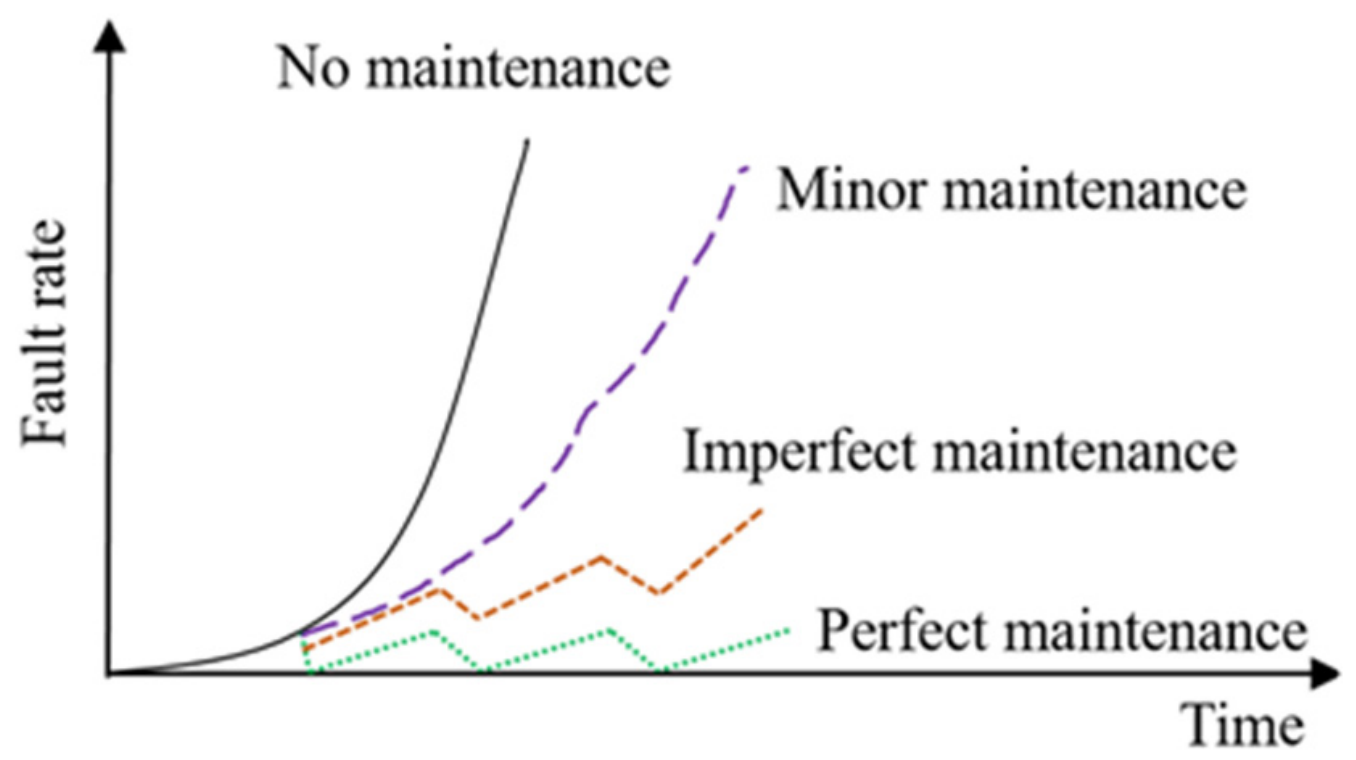

Figure 2. Variation curve of component fault rate under different maintenance modes. 
In addition, the maintenance time of various maintenance behaviors cannot be ignored. It is generally set according to the specific maintenance conditions of each piece of equipment. Generally, it can be assumed that the maintenance time is fixed or not fixed [39], and can follow uniform distribution, exponential distribution and Weibull distribution, etc. $[40,41]$.

\section{Influence of Equipment Dependency on Maintenance}

Industrial equipment has gradually developed to comprise multiple pieces of equipment [42]. Each piece of equipment is also composed of multiple components [43]. The equipment in a multiequipment system has some connections, and the components in multicomponent equipment also have some connections. In order to describe the connections specifically, only multicomponent equipment is introduced in the following, whereas, in the literature review, multiequipment systems and multicomponent equipment are introduced.

Multicomponent equipment usually consists of multiple identical or different components. These components can be connected in series, parallel, series parallel or redundancy $[44,45]$. If there is no correlation between these components, the maintenance behavior for multicomponent equipment can be arranged according to the characteristics of each component. In fact, there is usually an implicit correlation, which is called dependency, between different components in the equipment [46]. It is necessary to globally analyze the dependency between components and fully consider the interaction of maintenance operations between components, so as to achieve the optimal overall maintenance decision. The dependencies between components can be classified into economic dependence, random dependence, structural dependence and resource dependence [47]. The characteristics of the various dependencies are shown in Table 2.

Table 2. Dependencies among multiple components.

\begin{tabular}{cr}
\hline Dependency & Characteristics \\
\hline Economic dependence & $\begin{array}{r}\text { The cost of the joint maintenance of several } \\
\text { components is not equal to that of maintenance of } \\
\text { these components separately }\end{array}$ \\
Random dependence & $\begin{array}{c}\text { The failure of one component in a piece of } \\
\text { multicomponent equipment will affect the } \\
\text { performance of the other components }\end{array}$ \\
\hline Structural dependence & $\begin{array}{c}\text { For a multicomponent system with a cooperative } \\
\text { relationship between components, if one } \\
\text { component is repaired, the other components also } \\
\text { need to be removed or replaced }\end{array}$ \\
\hline Resource dependence & $\begin{array}{c}\text { Maintenance operations can only be carried out } \\
\text { when all required resources are available }\end{array}$ \\
\hline
\end{tabular}

\subsection{Economic Dependence}

Economic dependence means the cost of the joint maintenance of several components of the equipment is not equal to that of the individual maintenance of these components [48]. Usually, the joint maintenance of several components only requires the preparation of the required spare components and maintenance tools at one time. Only one group of maintenance personnel is required to disassemble and assemble the equipment [49]. Therefore, maintenance costs will be reduced. However, in some special cases, the joint maintenance of several components will increase the maintenance cost [50]. If additional maintenance personnel are assigned to the joint maintenance in a limited space, they will hinder each other. In this situation, maintenance efficiency will decrease and the maintenance cost will increase. The economic dependence in the former case is positive economic dependence and in the latter case is negative economic dependence [51]. 


\subsection{Random Dependence}

Random dependence means that the failure of one component in a piece of multicomponent equipment will affect the performance of the other components [52]. Murthy et al. [53] proposed two models to describe the random dependence of equipment with two components. One is that the failure of any component in the equipment will affect the other component. Another situation is that no matter which component fails, the other component will not be affected. For two component equipment with random dependence and economic dependence, Scarf et al. $[54,55]$ studied an age based replacement strategy and group replacement strategy, respectively. Zhang and Lai et al. [56,57] studied two component equipment with two random dependencies at the same time.

\subsection{Structural Dependence}

Structural dependence refers to a piece of multicomponent equipment in which there is a cooperative relationship between components [58]. If one component needs to be repaired due to failure, other components will also intervene in the maintenance process. This would result in the overlapping of the maintenance processes of multiple components [59]. For example, when one of the two components with a matching relationship is seriously damaged, the working state of the other component will also be affected, so it will need to be replaced. In addition, if the components to be repaired are blocked by other components, the hindering components need to be removed.

\subsection{Resource Dependence}

Resource dependence means that a maintenance operation can be scheduled only when required resources, such as spare components or maintenance tools, are available [60,61]. For example, when several components are connected through a set of shared limited spare components, resource dependence will occur. Therefore, the maintenance decision needs to be made at the equipment level rather than at the component level [62]. For example, if a manufacturer needs to go to the operation site of components or equipment for maintenance activities, maintenance personnel, tools and required spare components all need to be transported to the location where maintenance activities are to be performed. Transportation space is usually limited, so the resource transportation is limited. Therefore, priority rules need to be created to determine how to allocate this space in advance.

Considering that a variety of maintenance dependencies will make the maintenance decision model too complex to analyze, most existing research on multicomponent equipment focuses on the above two dependences.

\section{Maintenance Strategy}

The basic idea of a maintenance strategy is to achieve the optimization objectives of improving component reliability, increasing availability and reducing maintenance cost by reasonably planning maintenance under the condition of limited maintenance resources (such as spare parts, maintenance tools, maintenance personnel, etc.) [63]. The existing maintenance strategies can be divided into single component maintenance strategies and multicomponent maintenance strategies, according to the number of components [64].

\subsection{Overview Single Component Maintenance Strategies}

Based on the opportunity for maintenance activities, maintenance strategies can be divided into corrective maintenance, preventive maintenance and predictive maintenance, as shown in Figure 3. Table 3 lists the characteristics of each maintenance strategy. 


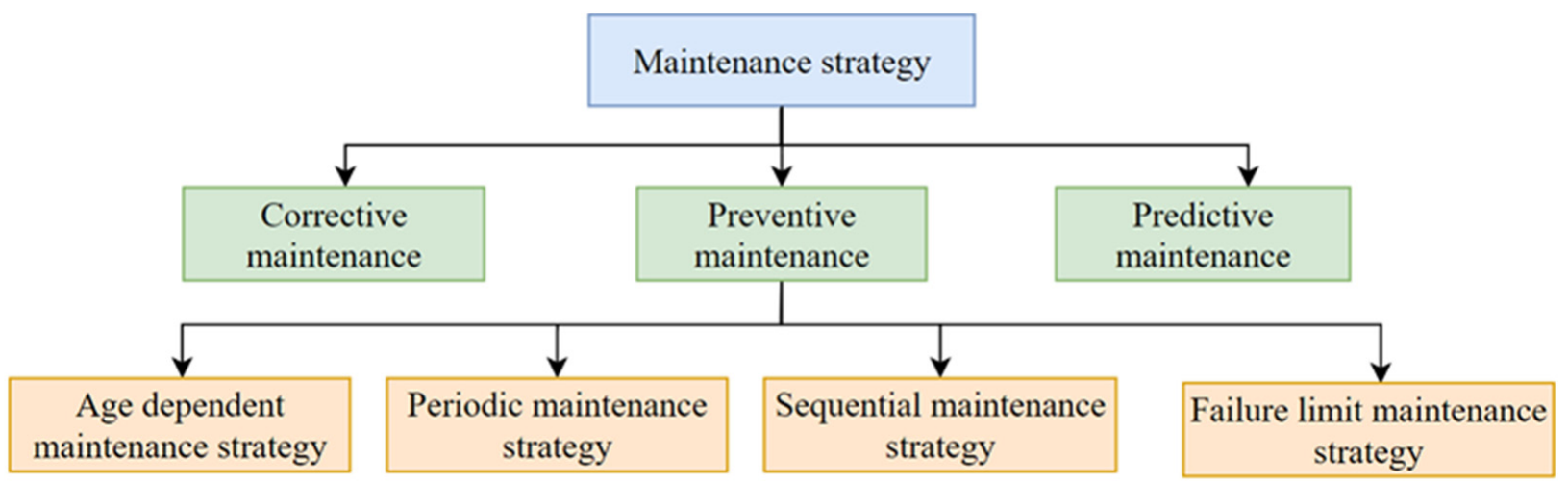

Figure 3. Classification of single component maintenance strategies.

Table 3. Classification and characteristics of single-component maintenance strategies.

\begin{tabular}{|c|c|c|c|}
\hline \multicolumn{2}{|c|}{ Maintenance Strategy } & Characteristics and Applicability & Limitations \\
\hline \multicolumn{2}{|c|}{ Corrective maintenance } & $\begin{array}{l}\text { The maintenance is carried out after the } \\
\text { components fail. This method is applicable to the } \\
\text { components whose service age is difficult } \\
\text { to ascertain. }\end{array}$ & $\begin{array}{l}\text { Problems such as interrupting the } \\
\text { normal working plan of } \\
\text { components and untimely } \\
\text { maintenance will occur. }\end{array}$ \\
\hline \multirow{4}{*}{$\begin{array}{l}\text { Preventive } \\
\text { maintenance }\end{array}$} & $\begin{array}{l}\text { Age dependent } \\
\text { maintenance strategy }\end{array}$ & $\begin{array}{c}\text { The maintenance time is determined according } \\
\text { to the service age of the components. This } \\
\text { method is applicable for components whose } \\
\text { service age is known. }\end{array}$ & $\begin{array}{l}\text { Leaves equipment prone to } \\
\text { insufficient maintenance. }\end{array}$ \\
\hline & $\begin{array}{l}\text { Periodic maintenance } \\
\text { strategy }\end{array}$ & $\begin{array}{l}\text { The interval between two maintenances is } \\
\text { constant. This method is suitable for components } \\
\text { with small fluctuations in degradation rate. }\end{array}$ & $\begin{array}{l}\text { The risk of failure due to an } \\
\text { increase in the rate of component } \\
\text { degradation cannot be avoided. }\end{array}$ \\
\hline & $\begin{array}{c}\text { Sequential } \\
\text { maintenance strategy }\end{array}$ & $\begin{array}{c}\text { The maintenance interval decreases step by step. } \\
\text { This method is applicable to components with } \\
\text { significant change characteristics of } \\
\text { degradation rules. }\end{array}$ & $\begin{array}{l}\text { Prone to a mismatch between } \\
\text { maintenance requirements and } \\
\text { maintenance operations. }\end{array}$ \\
\hline & Failure limit strategy & $\begin{array}{l}\text { The maintenance time is determined according } \\
\text { to the relationship between component reliability } \\
\text { and threshold. This method is suitable for } \\
\text { components with high reliability requirements. }\end{array}$ & $\begin{array}{l}\text { The threshold is difficult } \\
\text { to determine. }\end{array}$ \\
\hline \multicolumn{2}{|c|}{ Predictive maintenance } & $\begin{array}{l}\text { The maintenance opportunity is determined } \\
\text { according to the predicted component } \\
\text { degradation trend. } \\
\text { This method is applicable to components whose } \\
\text { degradation parameters can be monitored. }\end{array}$ & $\begin{array}{l}\text { It cannot be applied to } \\
\text { nonmonitorable components. }\end{array}$ \\
\hline
\end{tabular}

\subsubsection{Corrective Maintenance Strategies}

Corrective maintenance (also known as postfailure maintenance) was mainly used in the 1940s [65]. This strategy is driven by failure events. Only after component failure, are repair activities arranged [66]. Therefore, the normal working plan of components will be interrupted and some losses will be incurred. In addition, because failure events usually occur suddenly, this strategy is prone to untimely maintenance caused by the untimely preparation of maintenance resources [67]. This situation increases the failure loss of components, to a certain extent [68]. The many disadvantages of corrective maintenance stimulated the emergence and development of other maintenance strategies. However, due to the uncertainty of component failure, subsequent maintenance strategies are often considered together with corrective maintenance. 


\subsubsection{Preventive Maintenance Strategies}

Preventive maintenance strategies arrange maintenance activities according to the relationship between failure rate, failure time distribution, life distribution and their respective thresholds obtained from a large number of failure statistical data of similar components $[69,70]$. Their purpose is to reduce the failure possibility of service components [71]. According to the types of information, preventive maintenance can be further divided into age dependent maintenance strategies, periodic maintenance strategies, sequential maintenance strategies and failure limited maintenance strategies [72,73].

\section{Age dependent maintenance strategies}

Age-dependent maintenance strategies refer to when the status value of the component reaches a preset value at which replacement activity happens [74]. If the component fails before reaching the preset age value, the replacement happens immediately [75]. Scarf [76] introduced three maintenance effects, i.e., minor maintenance, imperfect maintenance and perfect maintenance, into the age dependent maintenance strategy. Through this, the optimal maintenance age, optimal detection interval and detection times are obtained by minimizing the maintenance loss per unit of time.

\section{Periodic maintenance strategy}

Periodic maintenance strategy refers to when maintenance activities are carried out at regular intervals [77]. This maintenance strategy does not need to consider the age of components, and the formulation process is simple and flexible [78]. However, it does not consider the difference in degradation rate at different stages of components, so it cannot decrease the risk of failure caused by the aggravation of component degradation rate in the later stages of service [79]. Considering these disadvantages, scholars have also made some improvements to this strategy. Nakagawa et al. [80] introduced the imperfect maintenance effect into the periodic maintenance strategy, so that the maintenance time interval is more in line with the actual situation. Qi et al. [81] proposed a three stage periodic maintenance strategy. It considers the difference in component degradation rates at different stages, and the maintenance intervals of these three stages are reduced, in turn.

\section{Sequential maintenance strategy}

A sequential maintenance strategy is an improvement of the periodic maintenance strategy [82]. It considers the increase in equipment degradation rate and failure frequency during service through successively reducing the maintenance time interval and increasing the maintenance frequency [83]. Nakagawa et al. [84] added a minor repair between two sequential maintenances to solve the problem of component failure between the two sequential maintenances. Dedopoulos et al. [85] assumed that maintenance costs fluctuate over time, and introduced this volatility into the sequential maintenance strategy. The optimal sequential maintenance time series of components in a finite life can be obtained. Lin et al. [86] proposed a sequential imperfect maintenance strategy for the case where the repairable failure mode and the nonrepairable failure mode are independent of each other. Xia et al. [87] introduced the influence of repair degree on component performance degradation trends and on maintenance cost into the maintenance cost model, and obtained the optimal sequential maintenance interval. Barlow et al. [88] introduced the increasing factor of failure rate into the reliability model and established a sequential maintenance model centered on reliability. Huang et al. [89] used the virtual age factor to characterize the recovery degree of equipment under three maintenance effects, i.e., perfect maintenance, imperfect maintenance and minor maintenance. The virtual age factor was also introduced into the failure rate model to characterize the impact of different maintenance modes on component failure rate.

A sequential maintenance strategy can make planned maintenance time more suitable for the actual situation by introducing various factors into the maintenance decision model. These factors, such as the decreasing age factor and the increasing failure rate factor, can characterize the different performance degradations of components at different service 
stages, to some extent. However, these factors are usually difficult to determine in engineering. Therefore, when factors have some deviation, mismatch between maintenance demand and maintenance operation can easily occur.

\section{Failure limit strategy}

Failure limit strategy refers to setting the maintenance opportunity according to the relationship between the failure rate, other reliability indexes of components and the threshold [90]. Lie [91] stipulated that a repair shall be carried out when the component failure rate reaches its threshold. If the component fails during operation, it shall be corrected through minor repair. Maillart et al. [92] divided the performance degradation process of components into two stages: the normal service stage with cycle $\mathrm{T} 1$ and performance degradation stage with cycle T2. No maintenance operation is carried out in the time period of $(0, \mathrm{~T} 1)$. Under $(\mathrm{T} 1, \mathrm{~T} 1+\mathrm{T} 2]$ maintenance is carried out within the time period. When the time is greater than $\mathrm{T} 1+\mathrm{T} 2$, the components are replaced. Since imperfect maintenance is usually described by failure rate and effective age, scholars combined minor maintenance, imperfect maintenance and perfect maintenance with a failure limited maintenance strategy to form a failure limited maintenance model with multiple influencing factors [93]. Malik et al. [94] proposed the aging reduction factor and introduced it into the failure rate function to characterize the change in component failure rate after maintenance. Nakagawa et al. [95] introduced the hazard increase factor into the failure rate function to characterize the impact of maintenance behavior on component degradation rate. Pan et al. [96] established the failure rate function, which combines the service age increasing factor and the effective service age factor. Based on this, the failure limited maintenance strategy is modeled.

As the failure limited maintenance strategy controls the reliability indexes, such as failure efficiency and failure rate, it is more suitable for components with high reliability requirements. The key to this strategy is to set a reasonable failure rate threshold in advance. In engineering, the failure rate threshold is difficult to ascertain.

To sum up, the most significant feature of a preventive maintenance strategy is that maintenance activities are formulated on the premise that the components can still work normally. Moreover, the set maintenance procedures, such as maintenance time, maintenance times and maintenance mode, are generally applicable to the same types of components. Therefore, this strategy has the characteristics of convenient setting and strong universality. At present, it is still the preferred maintenance strategy for most enterprises. Its disadvantages are also obvious: It ignores differences, such as in use degree and working environment, etc., so the maintenance activities obtained may not be optimal for each component. Secondly, once the maintenance activities are determined, they will not change with the actual operation state of the components. Therefore, in the maintenance cycle, there may be problems such as excessive maintenance or insufficient maintenance [97].

\subsubsection{Predictive Maintenance Strategies}

Predictive maintenance monitors the performance degradation process of components by using condition monitoring technology, predicting their status in the future, and constantly updating the maintenance scheme according to the prediction results [98]. Kaiser et al. [99] used the information from real time monitoring to estimate random parameters in an exponential degradation model, obtained the remaining useful life distribution of components, and arranged maintenance activities, accordingly. Elwany et al. [100] used real time monitoring data to continuously update the remaining useful life distribution, so as to obtain the maintenance and replacement time of components. In addition, the maintenance threshold in predictive maintenance can be updated immediately, according to the degradation degree of components. Sun et al. [101] used a modified two stage degradation model to describe the degradation process of components and dynamically determine their maintenance thresholds. Li et al. [102] used time series prediction technology to predict component reliability in real time, based on continuously collected degradation data. Maintenance strategies of dynamic updating of maintenance thresholds have also 
been designed. Zhou et al. [103] established a predictive maintenance strategy considering imperfect maintenance by introducing an age reduction factor and failure rate growth factor into the failure rate model. You et al. [104] established a sequential predictive maintenance strategy considering the impact of imperfect maintenance, and took the minor maintenance cost rate as the limiting condition to obtain a real time, updated preventive maintenance plan.

Predictive maintenance strategies can formulate immediate maintenance measures for equipment whose status can be monitored, and the maintenance operation can be dynamically updated with the change in equipment monitoring signals until the update stop conditions are met. Due to this feature, predictive maintenance strategies are only applicable to equipment whose condition can be monitored.

\subsection{Overview of Multicomponent Maintenance Strategies}

At present, existing multicomponent maintenance optimization strategies mainly include batch maintenance, opportunity maintenance and group maintenance $[105,106]$. The characteristics are shown in Table 4.

Table 4. Classification and characteristics of multicomponent maintenance strategies.

\begin{tabular}{|c|c|c|c|c|}
\hline \multicolumn{3}{|c|}{ Maintenance Strategy } & Definition & Characteristics \\
\hline \multicolumn{3}{|c|}{ Batch maintenance strategy } & $\begin{array}{l}\text { Carry out preventive maintenance } \\
\text { on multiple components of } \\
\text { equipment at the same time } \\
\text { according to the same } \\
\text { maintenance cycle. }\end{array}$ & $\begin{array}{l}\text { It is suitable for equipment } \\
\text { with a closed life cycle. This } \\
\text { strategy may cause cost waste } \\
\text { due to excessive maintenance. }\end{array}$ \\
\hline \multicolumn{3}{|c|}{ Opportunity maintenance strategy } & $\begin{array}{l}\text { When repairing a part of the } \\
\text { equipment, other parts of the } \\
\text { equipment that need to be } \\
\text { repaired soon are also repaired }\end{array}$ & $\begin{array}{l}\text { It may increase the average } \\
\text { maintenance cost of } \\
\text { components and reduce the } \\
\text { effective service time } \\
\text { of components. }\end{array}$ \\
\hline \multirow{4}{*}{$\begin{array}{l}\text { Group } \\
\text { maintenance } \\
\text { strategy }\end{array}$} & \multirow{2}{*}{ atic grouping } & Reparative group & $\begin{array}{l}\text { When the faulty components do } \\
\text { not affect the normal operation of } \\
\text { the equipment, they can be } \\
\text { repaired together when the } \\
\text { equipment is shut down due to } \\
\text { component failure. }\end{array}$ & $\begin{array}{l}\text { It is applicable to } \\
\text { multicomponent equipment } \\
\text { with a redundant design, and } \\
\text { these components can only } \\
\text { be repaired. }\end{array}$ \\
\hline & & Preventive group & $\begin{array}{l}\text { Adjust the maintenance time } \\
\text { interval of multiple components to } \\
\text { an integer multiple to increase the } \\
\text { coincidence probability of } \\
\text { component maintenance time. }\end{array}$ & $\begin{array}{l}\text { It is applicable to equipment } \\
\text { with a certain multiple } \\
\text { relationship between } \\
\text { component } \\
\text { maintenance intervals. } \\
\text { This strategy can reduce the } \\
\text { cost of resource preparation. }\end{array}$ \\
\hline & \multirow{2}{*}{$\begin{array}{l}\text { Dynamic } \\
\text { grouping }\end{array}$} & Finite time axis & $\begin{array}{l}\text { Within a limited time, the } \\
\text { maintenance cycle of multiple } \\
\text { components is dynamically } \\
\text { adjusted and updated. }\end{array}$ & $\begin{array}{l}\text { Only the maintenance methods } \\
\text { within a certain period are } \\
\text { planned. This strategy is } \\
\text { applicable to equipment with a } \\
\text { short life and low scrap cost. }\end{array}$ \\
\hline & & Scroll timeline & $\begin{array}{l}\text { Under no time limits, the } \\
\text { maintenance cycle of multiple } \\
\text { components is dynamically } \\
\text { adjusted and updated. }\end{array}$ & $\begin{array}{l}\text { It is suitable for equipment } \\
\text { with a long life, high scrap cost } \\
\text { and complex and changeable } \\
\text { service conditions. } \\
\text { Maintenance decisions can } \\
\text { reflect and track the health } \\
\text { status of equipment. }\end{array}$ \\
\hline
\end{tabular}




\subsubsection{Batch Maintenance Strategies}

Batch maintenance refers to the simultaneous preventive maintenance of multiple components in equipment according to the same maintenance cycle [107]. Moakedi et al. [108] established a maintenance strategy model for two components with random dependence, and obtained the optimal periodic maintenance interval based on a recursive equation and Monte Carlo simulation. Zequeira et al. [109] studied the periodic batch maintenance problem of two component equipment with random dependence, and gave the conditions for the existence and uniqueness of the optimal strategy. Park et al. [110] proposed a new batch maintenance strategy to avoid the waste of the maintenance cost of multiple components caused by traditional batch maintenance. Taking the maintenance cost of equipment as the optimization goal, the number of faults to prevent equipment failure and the optimal maintenance cycle of equipment were solved. The maintenance is carried out only when the fault number reaches the threshold. Sheu et al. [111] took multicomponent equipment whose performance degradation follows a nonhomogeneous accumulation process as the research object. The component faults in the equipment were divided into two types, i.e., degradation and sudden faults. For sudden faults, minor repair was adopted. The optimal batch maintenance cycle was solved with the cost rate and expected discount rate as the optimization objective.

Batch maintenance strategies are simple and easy, and have been widely used in industrial practice. However, these strategies will also repair the components in good condition in a maintenance cycle, which will inevitably lead to excessive maintenance and waste of maintenance resources.

\subsubsection{Opportunistic Maintenance Strategies}

Opportunistic maintenance means that, when a component of the equipment needs to be repaired, other components that need to soon be repaired are repaired in advance $[112,113]$. This strategy can reduce the incidence of equipment shutdown and maintenance and reduce the equipment maintenance cost [114]. Cai et al. [115] studied the opportunity maintenance probability density and renewal process of multiple components. The opportunity maintenance decision optimization model at the equipment level was also established with the expected maintenance cost rate as the optimization objective and the opportunity maintenance service age as the optimization variable. Ding et al. [116] analyzed the economic correlations in multiple components maintenance in a wind turbine. The occurrence of preventive maintenance or postfault maintenance of some components in the equipment was used to carry out opportunistic maintenance on other components. The simulation confirmed that the proposed opportunistic maintenance strategy could significantly reduce the maintenance cost. Koochaki et al. [117] took a series system composed of three pieces of equipment as the research object, and studied the impact of opportunistic maintenance on the effectiveness of predictive maintenance. They dynamically selected the opportunistic maintenance time, and verified the effectiveness of implementing the opportunistic maintenance strategy in multiple pieces of equipment. Hu et al. [118] proposed a maintenance decision model combining mechanical fault prediction and opportunistic maintenance. A dynamic Bayesian network was used to analyze the mechanical fault rate and minimize the maintenance cost on the basis of ensuring safety. Hou et al. [119] took equipment composed of multiple components in series as the research object, and introduced the repair non-new minor repair strategy into the opportunistic maintenance decision model. When some components of the equipment need to be shut down due to preventive maintenance, the minor repair or replacement of other components of the equipment were decided on, with the maintenance cost as the evaluation index. The maintenance cycle of opportunistic maintenance in the maintenance planning window was adjusted to obtain the optimal maintenance plan for the equipment.

The opportunistic maintenance strategy has strong practicability in engineering applications by repairing other components at the same time with the help of the maintenance opportunity of some components. However, this maintenance strategy will affect planned 
preventive maintenance plans, which may increase the average maintenance cost of components in the long run and reduce the effective service time of components in the life cycle. Therefore, opportunity maintenance can be adopted only when the cost of opportunity maintenance in advance is greater than the cost of any preventive maintenance originally planned.

\subsubsection{Group Maintenance Strategies}

Group maintenance is based on the idea that sharing the maintenance resources of the same type of components can save maintenance costs [120]. It can reduce maintenance costs by combining multiple components of the same type [121]. Compared with batch maintenance, group maintenance can repair multiple components according to different maintenance cycles. According to different decision-making methods, a group maintenance strategy can be divided into static group maintenance and dynamic group maintenance $[122,123]$.

\section{Static group maintenance strategy}

The static group maintenance strategy assumes that the equipment operates in a long term and stable working condition environment, and obtains the maintenance plan according to the static rules according to the long term historical operation state data of multiple components [124]. This plan does not make any adjustments during equipment operation [125]. This strategy is mostly used in multicomponent equipment with low reliability and high economic requirements, and all maintenance intervals are fixed. According to the timing of maintenance, static group maintenance can be further divided into corrective group maintenance and preventive group maintenance.

- Corrective group maintenance strategy

Corrective group maintenance strategy is mainly for multicomponent equipment with a redundant design, and the components in such equipment can only be repaired by the corrective maintenance method [126], as shown in Figure 4. When the failure of a single component does not affect the equipment operation, it can wait for the failure of multiple components for group maintenance.

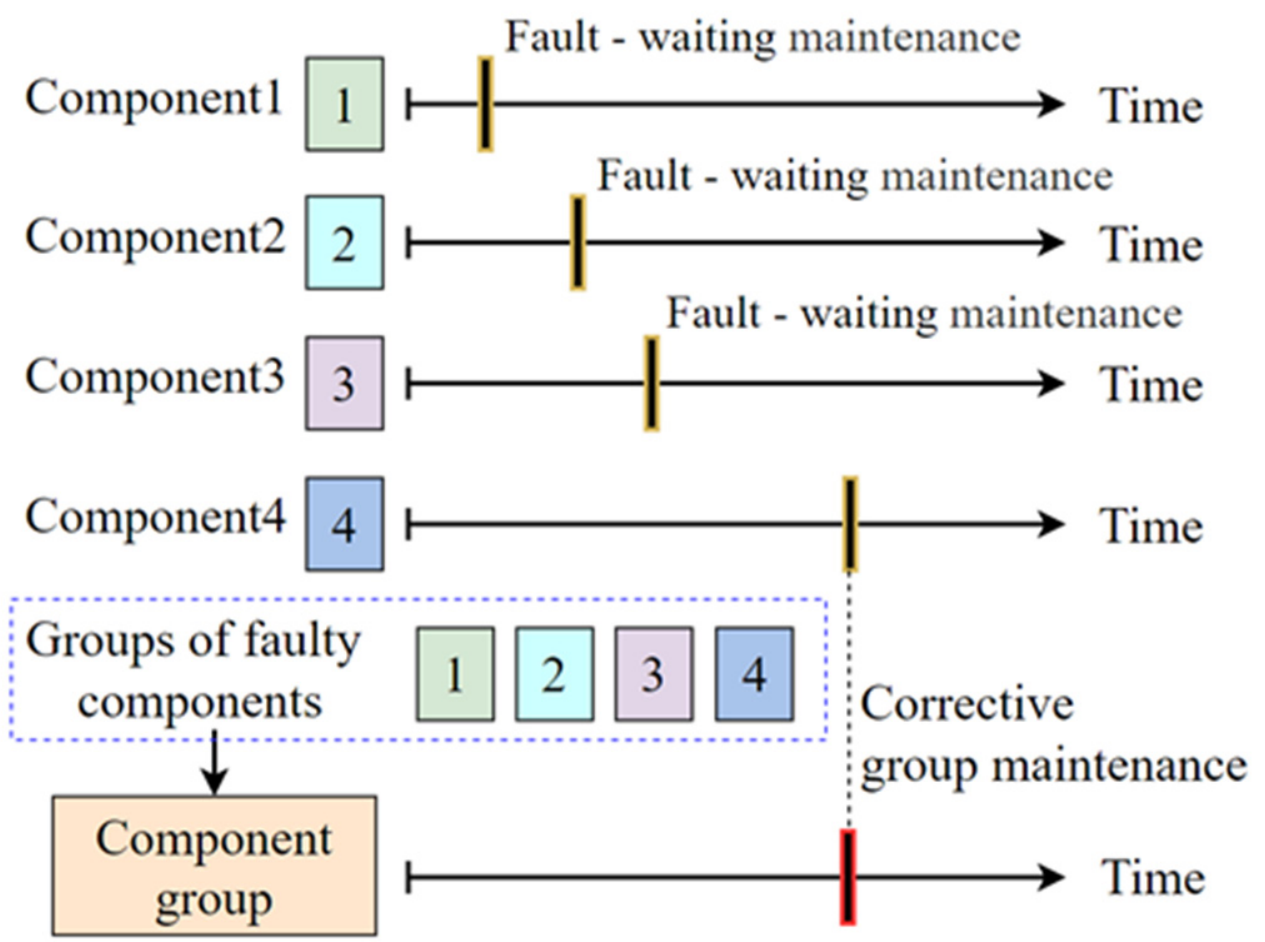

Figure 4. Corrective group maintenance. 
- $\quad$ Preventive group maintenance strategy

Preventive group maintenance is to set a benchmark maintenance interval that makes the preventive maintenance interval of multiple components an integral multiple [127], so as to increase the probability of the coincidence of maintenance times of various components, as shown in Figure 5. When the preventive maintenance time of two or more components coincides with the reference maintenance time interval, preventive group maintenance can be carried out for multiple components.
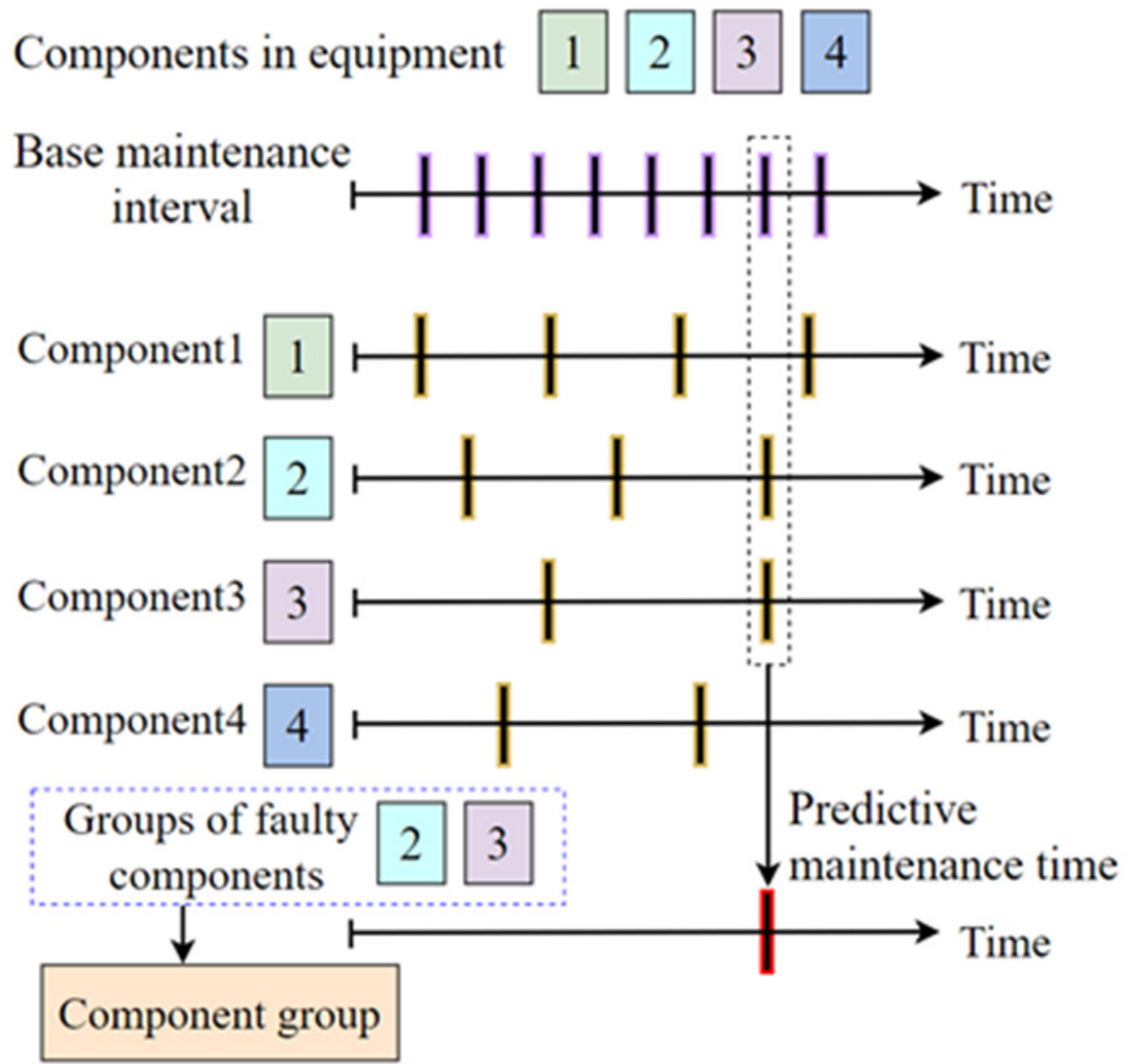

Figure 5. Preventive group maintenance.

Hai et al. [128] established a maintenance decision model with the maintenance cost of the system as the optimization objective, and proposed a heuristic optimization method to obtain the optimal group maintenance scheme. Yang et al. [129] divided the maintenance resource preparation cost in the preventive maintenance cost into two components: allocable and nonallocable. Taking the system maintenance cost as the optimization objective, a maintenance decision model was established, and the optimal group maintenance scheme of the system was determined by using the heuristic optimization algorithm. Chen et al. [130] took a ship lock system containing multiple components as the research object, took the maintenance economy of the multicomponent system as the optimization objective, took reliability as the constraint condition, and established a decision-making model by using the preventive group maintenance method. The simulation results showed that the model can minimize the annual average maintenance cost of the system. Cai et al. [131] established an aircraft preventive group maintenance decision optimization model with the periodic inspection interval and the maintenance task interval of each component as the optimization variables, and took the aircraft air conditioning system as an example. 


\section{Dynamic group maintenance}

Dynamic group maintenance is to dynamically adjust the maintenance activities of multiple components according to the real time status information of each component in the equipment [132,133], as shown in Figure 6. After each maintenance activity, the status information of each component in the equipment is updated in time to reflect and track the changes in equipment health status as much as possible, so as to achieve the optimal maintenance effect [134]. Dynamic group maintenance is often used in multicomponent equipment with high reliability requirements. Compared with static group maintenance, it can bring the status information of equipment components into the maintenance decisionmaking, and dynamically adjust the maintenance time in the maintenance cycle.
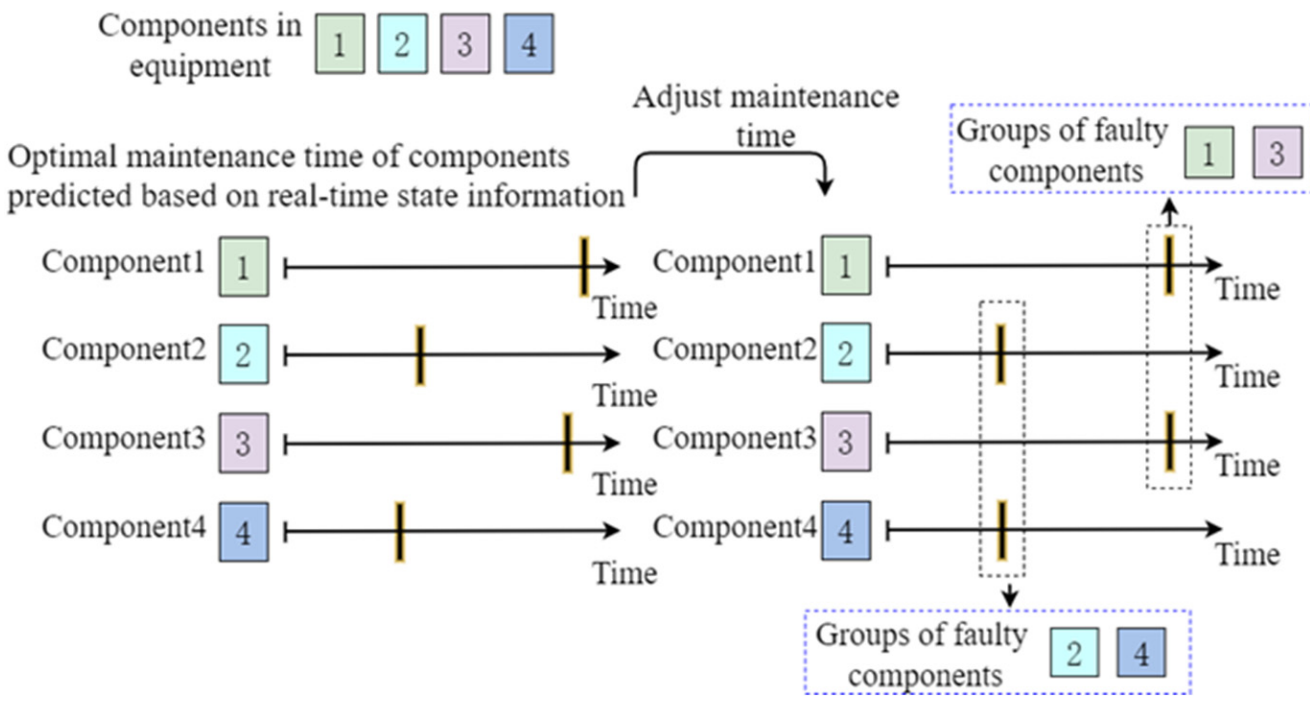

Figure 6. Dynamic group maintenance.

According to the time span of decision-making, dynamic group maintenance can be divided into finite time axis and rolling time axis methods.

- $\quad$ The finite time axis method

The finite time axis method is to plan the maintenance strategy within the time set at an early stage, and no maintenance plan will be made after this time $[135,136]$. Therefore, this method can be used to make maintenance plans for equipment with a short service life and low scrap cost.

- The rolling time axis method

The rolling time axis method is a maintenance planning method that repeatedly uses the finite time axis model to expand the plan from a limited time to a long term infinite time plan [137]. Each time the maintenance plan is completed or new status information appears, a new maintenance planning is carried out to make the maintenance decision-making time window roll continuously. This strategy is applicable to equipment with a long service life and high scrapping cost. In addition, it is also applicable to the maintenance decision-making for equipment serving in complex and changeable working conditions and environments.

Do et al. [138] took a multiequipment system composed of a series as the research object, incorporated constraints such as limited downtime maintenance during operation and the difference and limitation of maintenance resources in each operation period of the system into the decision-making, and proposed a dynamic group maintenance strategy based on the rolling time axis model. Wildeman et al. [139], Hai et al. [140] and Do et al. [141] proposed different multicomponent dynamic group maintenance decision models, but the maintenance time was not considered in the modeling process to reduce the complexity of 
the model. Aizpurua et al. [142], Barron et al. [143], Tian et al. [144] and Wang et al. [145] did not consider multiple maintenances of the same component in the maintenance decision window in the process of multi-component dynamic group maintenance decision modeling, so as to reduce the difficulty of model solution.

It can be seen from the above that the dynamic group maintenance model can incorporate the real time state information of equipment into the maintenance decision, realize on demand maintenance, to a certain extent, and reduce system maintenance costs. However, the complexity of the model is much higher than that of the static group maintenance strategy.

\section{Application of Maintenance Strategies in Some Industries}

In recent years, various maintenance strategies have been applied in industry [146]. This part summarizes the maintenance strategies and methodologies applied in industry in the past 5 to 10 years. The summarized industrial fields mainly include aviation, rail transit and energy.

\subsection{Aviation Industries}

The maintenance decision of aviation equipment changes from regular preventive maintenance to predictive maintenance based on equipment status. That is, while ensuring the functionality of the system, continuously understanding the degradation state of the system according to the main data of the equipment. At the same time, the predictive maintenance strategy is formulated with reference to the flight time, cycle, calendar month and other factors of aviation equipment [147]. Before the system failure, the equipment shall be repaired as necessary to reduce the maintenance cost as much as possible.

At present, in aviation fields, a predictive maintenance strategy based on condition detection technology has been applied in hydraulic systems [148], aeroengines [149,150], fuselage structures [151,152], tire pressures [153], etc. The most commonly used optimization models of a predictive maintenance strategy in aviation equipment include a state space model [154], delay time model [155], counting process detection [156], impact model [157], proportional hazard model [158] and Markov model [159], etc.

\subsection{Rail Transit Industries}

Rail transit industries mainly include high speed railway and urban rail transit. The key equipment in the high speed railway industry generally adopts multilevel preventive maintenance $[160,161]$. The maintenance level is usually divided according to running kilometers [162]. Class I maintenance is carried out after having driven for about $30,000 \mathrm{~km}$, class II maintenance is carried out after having driven for about 100,000 km, class III maintenance is carried out after having driven for $300,000 \mathrm{~km}$ and class IV maintenance is carried out after having driven for $600,000 \mathrm{~km}$ [163]. Level I overhaul is carried out at 1.2 million $\mathrm{km}$ and level II overhaul is carried out after having driven for 3.6 million $\mathrm{km}$ [164]. If a fault is diagnosed when the train has not entered the maintenance base, the train running condition will be adjusted accordingly, according to the fault level $[165,166]$. Multilevel preventive maintenance [167] is mainly applied to pantographs [168], catenaries [169] and other equipment or components. The most commonly used maintenance strategy optimization models [170] and solution algorithms [171] include a mixed integer programming model [172], stochastic optimization model [173] and dynamic programming algorithm [174], etc.

Urban rail transit mainly adopts time based preventive maintenance and temporary maintenance [175]. Time based preventive maintenance mainly includes weekly inspection, quarterly inspection, semi-annual inspection, annual inspection, medium repair, overhaul and other methods. The time of each maintenance cycle can be slightly adjusted. For example, the maximum advance and delay days of quarterly inspection are 10 days, and the maximum advance and delay days of annual inspection are 30 days [176]. Temporary maintenance mainly includes daily maintenance, fault emergency treatment and emer- 
gency rescue [177]. Preventive maintenance is mainly applied to switch machines [178], interlocking and other equipment [179,180]. Genetic algorithm [181] and particle swarm optimization algorithm [182] are often used.

\subsection{Energy Industries}

The maintenance of the energy industry mainly includes the maintenance of energy equipment and energy transmission lines. Among them, the maintenance of energy equipment is usually based on the predictive maintenance strategy [183]. This maintenance strategy is formulated according to the equipment status data, energy grid operation data and dynamic data [184]. This maintenance strategy can provide the predicted alarm data to the maintenance personnel, so that the maintenance personnel can arrange the maintenance work in advance [185]. The technology often used in this maintenance strategy is anomaly analysis [186], support vector machine [187], hybrid structured multicriteria decision-making method based on fuzzy Delphi [188], multicomponent condition based opportunistic maintenance and operations model [189], etc. For equipment with low failure frequency and small failure impact, a periodic maintenance strategy is often formulated based on reliability data [190].

The maintenance strategy of power transmission lines is based on regular preventive maintenance, which usually takes the sum of operation, interruption, maintenance and environmental costs as the objective functions [191]. Taking the fault type, fault time interval, maintenance difficulty and safety of the cable as constraints [192], the maintenance time interval is formulated. By arranging personnel in key areas to maintain power transmission lines regularly, the safe operation of power transmission lines can be ensured [193,194]. Multi criteria decision-making methods, such as an analytic hierarchy process, complex proportional assessment and integer programming, are often used to obtain the maintenance interval [195].

\section{Conclusions and Future Challenges}

Through an investigation of the literature related to maintenance decisions, this paper systematically summarizes the equipment maintenance strategies used in industrial systems. Firstly, starting from single component maintenance, the characteristics, application potential and limitations of corrective maintenance, preventive maintenance and predictive maintenance are described in detail. Secondly, based on the dependency between multiple components, the development and current situation of multicomponent maintenance strategies, such as batch maintenance, opportunity maintenance and group maintenance, are summarized. Their advantages and disadvantages are analyzed, and the future development directions of industrial equipment maintenance strategies are discussed.

When various maintenance strategies are applied to practical industrial equipment, many practical problems and challenges have to be faced. These challenges and problems have certain research value and need to be further discussed and studied. Therefore, this paper summarizes the problems that have not yet been well studied:

- Maintenance Strategies for Key Equipment with Limited Condition Monitoring

Due to the limited condition monitoring of some key equipment, it is difficult to continuously obtain data characterizing its degradation. Therefore, two traditional maintenance strategies, corrective maintenance and preventive maintenance, are still the most commonly used strategies in practical application. The maintenance methods formulated by these two strategies are far from the actual maintenance requirements. Thus, excessive repair and insufficient maintenance often occur, and may even lead to major accidents. These disadvantages make it necessary to further explore the predictive maintenance strategy for key equipment with limited condition monitoring.

Considering the large amount of the textual information, such as alarm information and external environment change information, of key equipment in actual operation is usually stored, if it can be further developed and extracted, it will help to formulate efficient maintenance strategies. At present, this information can reflect the state of the equipment, 
to a certain extent. However, there is no mature method to quantitatively characterize the state of equipment by using this textual information. Therefore, it remains a challenge to evaluate the status of this key equipment according to indirect information, such as equipment alarm information and equipment environment change information, and use it in the formulation of maintenance strategies.

- Multicomponent Maintenance Strategy Considering Maintenance Constraints

In the process of formulating a multicomponent maintenance strategy, most industries only consider one or two dependencies between components and ignore other dependencies. In addition, there are few practical application cases that comprehensively consider the correlation between the number of maintenance parts, maintenance times, maintenance time and maintenance cost. This simplified maintenance decision-making method will lead to the problem that the maintenance suggestions are inconsistent with the actual maintenance requirements to a certain extent.

In order to obtain an accurate maintenance plan without losing efficiency, various industries need to establish a more comprehensive multicomponent maintenance association relationship model. In the model, the relationship between the number of maintenance parts, maintenance times, maintenance time and maintenance cost is considered as much as possible to form a maintenance strategy more in line with actual needs.

Author Contributions: J.Z., C.G. and T.T. equally contributed to the present research and to the preparation of the paper. All authors have read and agreed to the published version of the manuscript.

Funding: This work was research was funded by the National Key R\&D Program of China, grant number 2020YFB1600705, and the Beijing Science and Technology Project, grant number Z191100002519003.

Data Availability Statement: All data in this study are available in the documents referenced in bibliography.

Conflicts of Interest: Authors declare no conflict of interest.

\section{References}

1. Shen, X.; Moere, A.; Eades, P. Evaluation of a maintenance strategy by the analysis of the rate of repair. Int. J. Ambient. Comput. Intell. 2010, 2, 59-69.

2. Richard, C.; Cassady, W. Selective maintenance for support equipment involving multiple maintenance actions. Eur. J. Oper. Res. 2001, 129, 252-258. [CrossRef]

3. Mohril, R.S.; Solanki, B.S.; Lad, B.K. Blockchain Enabled Maintenance Management Framework for Military Equipment. IEEE Trans. Eng. Manag. 2021, 5, 1-14. [CrossRef]

4. Nardo, M.D.; Madonna, M. A mapping analysis of maintenance in industry 4.0. J. Appl. Res. Technol. 2021, 19, 653-675. [CrossRef]

5. Ron, S.; Amanda, P. Costliest Disaster in US History; Financial Toll Passes $\$ 60$ Billion, Reaching from Wreckage and Airport Downtime to Lower Productivity and Lost Taxes. In Tribology, 2nd ed.; McGraw-Hill: New York, NY, USA, 2002; Volume 5, pp. 16-24.

6. Mehmeti, X.; Mehmeti, B.; Sejdiu, R. The equipment maintenance management in manufacturing enterprises. IFAC-PapersOnLine 2018, 51, 800-802. [CrossRef]

7. Christer, A. A Review of Delay Time Analysis for Modelling Plant Maintenance; Springer: Berlin/Heidelberg, Germany, 2002.

8. Polese, F.; Gallucci, C.; Carrubbo, L. Predictive Maintenance-as a driver for corporate sustainability: Evidence from a publicprivate co-financed R\&D project. Sustainability 2021, 13, 5884.

9. Kihira, H. Systematic approaches toward minimum maintenance risk management methods for weathering steel infrastructures. Corros. Sci. 2007, 49, 112-119. [CrossRef]

10. Mungani, D.S.; Visser, T. Maintenance approaches for different production methods. S. Afr. J. Ind. Eng. 2013, 24, 2224-7890. [CrossRef]

11. Shafiee, M.; Chukova, S. Maintenance models in warranty: A literature review. Eur. J. Oper. Res. 2013, 229, 561-572. [CrossRef]

12. Erkoyuncu, J.A.; Khan, S.; Eiroa, A.L. Perspectives on trading cost and availability for corrective maintenance at the equipment type level. Reliab. Eng. Syst. Saf. 2017, 168, 53-69. [CrossRef]

13. Halmai, Z.; Dome, P.; Dobos, J. Realization of corrective maintenance activities by application of different information systems. J. Affect. Disord. 2012, 144, 269-273. [CrossRef] [PubMed]

14. Wang, J. Research on Generator Maintenance Plan under the Environment of Power Market; China Agricultural University: Beijing, China, 2004. 
15. Liao, C.J.; Chen, W. Single-machine scheduling with periodic maintenance and nonresumable jobs. Comput. Oper. Res. 2003, 9, 1335-1347. [CrossRef]

16. Yam, R.; Tse, P.W.; Li, L. Intelligent predictive decision support system for condition-based maintenance. Int. J. Adv. Manuf. Technol. 2001, 17, 383-391. [CrossRef]

17. Mur, E.; Kopf, U.; Fluckinger, G. Adaptive signal analysis and interpretation for real-time intelligent patient monitoring. Methods Inf. Med. 1994, 33, 60-63.

18. Ma, G.; Jiang, L.; Xu, G. A Model of Intelligent Fault Diagnosis of Power Equipment Based on CBR. Math. Probl. Eng. 2015, 3, 203083. [CrossRef]

19. Hobbs, T.R. Depression in the Caregiving Mothers of Adult Schizophrenics: A Test of the Resource Deterioration Model. Community Ment. Health J. 1997, 33, 387-399. [CrossRef]

20. Jian, L.; Lin, B.; Wang, Z. A Pragmatic Optimization Method for Motor Train Set Assignment and Maintenance Scheduling Problem. Discret. Dyn. Nat. Soc. 2016, 6, 4540503.

21. Ke, L.; Kwong, S.; Cao, J. Achieving balance between proximity and diversity in multi-objective evolutionary algorithm. Inf. Sci. 2012, 182, 220-242.

22. Coria, V.H.; Maximov, S.; Rivas, D. Analytical method for optimization of maintenance policy based on available system failure data. Reliab. Eng. Syst. Saf. 2015, 135, 55-63. [CrossRef]

23. Tsao, Y.C. A piecewise nonlinear optimization for a production-inventory model under maintenance, variable setup costs, and trade credits. Ann. Oper. Res. 2013, 23, 56-68. [CrossRef]

24. 3187-94; State Bureau of Technical Supervision GB/T3187-94 Reliability and Maintainability Terms. Standards Press of China: Beijing, China, 1986.

25. Nardo, M.D.; Converso, G.; Castagna, F. Development and implementation of an algorithm for preventive machine maintenance. Eng. Solid Mech. 2021, 4, 347-362. [CrossRef]

26. Cornelia, B.; Marc, R.; Doru, N. Approaching the Processes in the Generator Circuit Breaker at Disconnection through Sustainability Concepts. Sustainability 2013, 5, 1161-1176.

27. Xia, T.; Xi, L.; Zhou, X. Modeling and optimizing maintenance schedule for energy systems subject to degradation. Comput. Ind. Eng. 2012, 63, 607-614. [CrossRef]

28. Chung, S.H.; Chan, F.; Chan, H.K. A modified genetic algorithm approach for scheduling of perfect maintenance in distributed production scheduling. Eng. Appl. Artif. Intell. 2009, 22, 1005-1014. [CrossRef]

29. Huynh, K.T.; Barros, A.; Berenguer, C. A periodic inspection and replacement policy for systems subject to competing failure modes due to degradation and traumatic events. Reliab. Eng. Syst. Saf. 2011, 96, 497-508. [CrossRef]

30. Noroozi, A.; Khakzad, N.; Khan, F. The role of human error in risk analysis: Application to pre- and post-maintenance procedures of process facilities. Reliab. Eng. Syst. Saf. 2013, 119, 251-258. [CrossRef]

31. Derkenne, C.; Jost, D.; Haruel, P.A. Insufficient quality of public automated external defibrillator recordings in the greater Paris area, a descriptive study. Emerg. Med. J. 2020, 37, 78-91. [CrossRef]

32. Dong, W.; Liu, S.; Bae, S.J.; Liu, Y. A multi-stage imperfect maintenance strategy for multi-state systems with variable user demands. Comput. Ind. Eng. 2020, 14, 106-118. [CrossRef]

33. Liu, Y.; Guo, P.; Zhang, C. Fleet-Level Selective Dispatch and Imperfect Maintenance Strategy Optimization Based on Evolutionary Co-Petition Game Theory. IEEE Access 2020, 8, 689-701. [CrossRef]

34. Hajjej, Z.; Dellagi, S.; Rezg, N. An optimal production/maintenance planning under stochastic random demand, service level and failure rate. IEEE Int. Conf. Autom. Sci. Eng. 2009, 18, 22-25.

35. Zhu, M. A new framework of complex system reliability with imperfect maintenance policy. Ann. Oper. Res. 2021, 13, 7913-7927. [CrossRef]

36. Liu, G.; Chen, S.; Jin, H. Optimum opportunistic maintenance schedule incorporating delay time theory with imperfect maintenance. Reliab. Eng. Syst. Saf. 2021, 213, 107-128. [CrossRef]

37. Li, X.; Ran, Y.; Wan, F. Condition-based maintenance strategy optimization of meta-action unit considering imperfect preventive maintenance based on Wiener process. Flex. Serv. Manuf. J. 2021, 1, 1-30. [CrossRef]

38. Gao, H.; Zhang, X.; Yang, X. Optimal Selective Maintenance Decision-Making for Consecutive-Mission Systems with Variable Durations and Limited Maintenance Time. Math. Probl. Eng. 2021, 21, 5534659. [CrossRef]

39. Chen, D.; Trivedi, K.S. Optimization for condition-based maintenance with semi-Markov decision process. Reliab. Eng. Syst. Saf. 2017, 90, 25-29. [CrossRef]

40. Nanasi, T. Interval Censored Data Analysis with Weibull and Exponential Distribution. Appl. Mech. Mater. 2014, 693, 74-79. [CrossRef]

41. Liao, H.; Elsayed, E.A.; Chan, L.Y. Maintenance of continuously monitored degrading systems. Eur. J. Oper. Res. 2006, 175, 821-835. [CrossRef]

42. Su, X.; Cheng, Z.; Luo, B. An Auxiliary Industrial Equipment Maintenance System Using Mixed Reality. In Proceedings of the IEEE 8th International Conference on Industrial Engineering and Applications, Chengdu, China, 23-26 April 2021.

43. Purnachand, K.; Shabbeer, M.; Nvsrm, P. Predictive Maintenance of Machines and Industrial Equipment. In Proceedings of the IEEE International Conference on Communication Systems and Network Technologies, Bhopal, India, 18-19 June 2021. 
44. Ostadi, B.; Hamedankhah, R. A two-stage reliability optimization approach for solving series-parallel redundancy allocation problem considering the sale of worn-out parts. Ann. Oper. Res. 2021, 304, 381-396. [CrossRef]

45. Hu, Y.; Ding, Y.; Zeng, Z. Redundancy optimization for multi-state series-parallel systems using ordinal optimization-basedgenetic algorithm. J. Risk Reliab. 2021, 236, 151-167. [CrossRef]

46. Chang, W.D.; Cha, H.S.; Im, C.H. Removing the Interdependency between Horizontal and Vertical Eye-Movement Components in Electrooculograms. Sensors 2016, 16, 227. [CrossRef]

47. Thomas, L. A survey of maintenance and replacement models for maintainability and reliability of multi-item systems. Reliab. Eng. Syst. Saf. 1986, 16, 297-309. [CrossRef]

48. Costa, R.N.; Simes, J.M. The Political and Economic Dependence of the Press in Macao under Portuguese and Chinese Rule: Continuity and Change. Commun. Soc. 2021, 34, 29-40. [CrossRef]

49. Mondal, B. Impact of state of economic dependence and employment status on the self-perceived health of Indian elderly people across expenditure quintiles of households. Ageing Soc. 2021, 5, 1-23. [CrossRef]

50. Kamana, P.; Ochuodho, T.O. Forest Sector Dependence and Economic Well-Being in Kentucky: An Econometric Analysis. For. Sci. 2021, 67, 659-669.

51. Nicolai, R.; Dekker, R. Optimal maintenance of multi-component systems: A review. Complex Syst. Maint. Handb. 2006, $116,263-286$.

52. Arijit, C.; Rajat, S.H.; Deepayan, S. From random matrices to long range dependence. Random Matrices Theory Appl. 2016, 5,1650008

53. Murthy, D.; Nguyen, D. Study of two-component system with failure interaction. Nav. Res. Logist. Q. 1985, 32, 239-247. [CrossRef]

54. Scarf, P.A.; Deara, M. On the development and application of maintenance policies for a two component system with failure dependence. IMA J. Manag. Math. 1998, 9, 91-108. [CrossRef]

55. Scarf, P.A.; Deara, M. Block replacement policies for a two-component system with failure dependence. Nav. Res. Logist. 2003, 50, 70-87. [CrossRef]

56. Zhang, Z.; Su, W.; Li, B. Opportunistic maintenance policy for a two-unit system with failure interactions. J. Tsinghua Univ. Sci. Technol. 2012, 52, 18-24.

57. Lai, M.T.; Chen, Y.C. Optimal periodic replacement policy for a two-unit system with failure rate interaction. Int. J. Adv. Manuf. Technol. 2006, 29, 367-371. [CrossRef]

58. Hossain, S.; Stephens, L.I.; Mauzeroll, J. Structural dependence of effective mass transport properties in lithium battery electrodes. J. Power Sources 2021, 504, 230069. [CrossRef]

59. Uhlmann, E.; Otto, F. Processes for the Introduction of the Maintenance Service Support System. Procedia CIRP 2014, 16, 332-337. [CrossRef]

60. Davis, G.F.; Cobb, J.A. Resource Dependence Theory: Past and Future. Res. Sociol. Organ. $2010,28,21-42$.

61. Drees, J.M.; Heugens, P. Synthesizing and Extending Resource Dependence Theory: A Meta-Analysis. J. Manag. 2012, 39, 1666-1698. [CrossRef]

62. Klauer, K.C.; Teige, M.S. Controllability and resource dependence in automatic evaluation. J. Exp. Soc. Psychol. 2007, 43, 648-655. [CrossRef]

63. Peng, Y.; Zuo, D. Current status of machine prognostics in condition-based maintenance: A review. Int. J. Adv. Manuf. Technol. 2006, 50, 297-313. [CrossRef]

64. Cortes, Y.I.; Berry, D.C.; Perreira, K.M. A multi-component, community-engaged intervention to reduce cardiovascular disease risk in perimenopausal Latinas: Pilot study protocol. Pilot Feasibility Stud. 2021, 7, 107092. [CrossRef]

65. Lucia, A.D.; Pompella, E.; Stefanucci, S. Assessing effort estimation models for corrective maintenance through empirical studies. Inf. Softw. Technol. 2005, 47, 3-15. [CrossRef]

66. Farhat, H. Maintenance: Availability and reliability. In Operation, Maintenance, and Repair of Land-Based Gas Turbines; Elsevier: Amsterdam, The Netherlands, 2021; Volume 14, pp. 89-106.

67. Wang, Y.H.; Deng, C.; Wu, J.; Wang, Y.C.; Xiong, Y. A corrective maintenance scheme for engineering equipment. Eng. Fail. Anal. 2014, 36, 269-283. [CrossRef]

68. Wang, W.; Zhang, W. An asset residual life prediction model based on expert judgments. Eur. J. Oper. Res. $2008,188,496-505$. [CrossRef]

69. Charles, A.S.; Floru, I.R.; Azzaro, P.C. Optimization of preventive maintenance strategies in a multipurpose batch plant: Application to semiconductor manufacturing. Comput. Chem. Eng. 2003, 27, 449-467. [CrossRef]

70. Dong, F.; Wang, H.; Men, F. Customized Preventive Maintenance Strategies for Products Sold with Two-Dimensional Warranty. Math. Probl. Eng. 2021, 2021, 5576455. [CrossRef]

71. Heng, A.; Zhang, S.; Tan, A. Rotating machinery prognostics: State of the art, challenges and opportunities. Mech. Syst. Signal Processing 2009, 23, 724-739. [CrossRef]

72. MD, R.; Laseinde, O. Optimization of condition-based maintenance strategy prediction for aging automotive industrial equipment using FMEA. Procedia Comput. Sci. 2021, 16, 229-238.

73. Torres-González, M.; Prieto, A.J.; Alejandre, F.J. Digital management focused on the preventive maintenance of World Heritage Sites. Autom. Constr. 2021, 129, 103813. [CrossRef] 
74. Kenné, P.; Gharbi, A.; Beit, M. Age-dependent production planning and maintenance strategies in unreliable manufacturing systems with lost sale. Eur. J. Oper. Res. 2007, 178, 408-420. [CrossRef]

75. Park, M. Replacement model under warranty with age-dependent minimal repair. Int. J. Reliab. Appl. 2017, 18, 9-20.

76. Scarf, P.A.; Cavalcante, C.; Dwight, R.A. An age-based inspection and replacement policy for heterogeneous components. IEEE Trans. Reliab. 2009, 58, 641-648. [CrossRef]

77. Artiba, A.; Jamali, M.A.; Ait-Kadi, D. Joint optimal periodic and conditional maintenance strategy. J. Qual. Maint. Eng. 2005, 11, 107-114. [CrossRef]

78. Nakagawa, T. Periodic inspection policy with preventive maintenance. Nav. Res. Logist. Q. 2010, 31, 33-40. [CrossRef]

79. Zhou, H.; Tsai, Y.C.; Huang, S. Single-Machine Scheduling with Fixed Periodic Preventive Maintenance to Minimise the Total Weighted Completion Times. Math. Probl. Eng. 2021, 2021, 8891322. [CrossRef]

80. Nakagawa, T. Optimum policies when preventive maintenance is imperfect. IEEE Trans. Reliab. 1979, 28, 331-332. [CrossRef]

81. Qi, X.I.; Cao, J.P.; Chen, G.M.; Change, L. Research on a phased periodic preventive maintenance model based on reliability constraint. Acta Armamentarii 2017, 38, 2251-2258.

82. Park, M.; Jung, K.M.; Dong, H.P. Optimal maintenance and warranty strategy for second-hand roduct with periodic preventive maintenance action. J. Korean Stat. Soc. 2021, 50, 773-794. [CrossRef]

83. Yang, Y.; Xie, H. Determination of Optimal MR\&R Strategy and Inspection Intervals to Support Infrastructure Maintenance Decision Making. Sustainability 2021, 13, 2664.

84. Nakagawa, T. Periodic and sequential preventive maintenance policies. J. Appl. Probab. 1986, 23, 536-542. [CrossRef]

85. Dedopoulos, I.T.; Smeers, Y. An age reduction approach for finite horizon optimization of preventive maintenance for single units subject to random failures. Comput. Ind. Eng. 1998, 34, 643-654. [CrossRef]

86. Lin, D.; Zuo, M.J.; Yam, R. Sequential imperfect preventive maintenance models with two categories of failure modes. Nav. Res. Logist. 2001, 48, 172-178. [CrossRef]

87. Xia, T.; Xi, L.; Lee, J.; Zhou, X. Optimal CBPM policy considering maintenance effects and environmental condition. Int. J. Adv. Manuf. Technol. 2011, 56, 1181-1193. [CrossRef]

88. Barlow, R.; Hunter, L. Optimum preventive maintenance policies. Oper. Res. 1960, 8, 90-100. [CrossRef]

89. Huang, J.; Chang, Q.; Zou, J. A real-time maintenance policy for multi-stage manufacturing systems considering imperfect maintenance effects. IEEE Access 1960, 8, 90-100. [CrossRef]

90. Bo, B. Optimal replacement under a general failure model. Adv. Appl. Probab. 1978, 10, 431-451.

91. Lie, C.; Chun, Y. An algorithm for preventive maintenance policy. IEEE Trans. Reliab. 1986, 35, 71-75. [CrossRef]

92. Maillart, L.M.; Pollock, S.M. Cost-optimal condition-monitoring for predictive maintenance of 2-phase systems. IEEE Trans. Reliab. 2002, 51, 322-330. [CrossRef]

93. Pham, H.; Wang, H. Imperfect maintenance. Eur. J. Oper. Res. 1996, 94, 425-438. [CrossRef]

94. Malik, M. Reliable Preventive Maintenance Scheduling. AIIE Trans. 1979, 11, 221-228. [CrossRef]

95. Nakagawa, T. Sequential imperfect preventive maintenance policies. IEEE Trans. Reliab. 1988, 37, 295-298. [CrossRef]

96. Pan, E.; Liao, W.; Xi, L. A single machine-based scheduling optimization model integrated with preventive maintenance policy for maximising the availability. Int. J. Ind. Syst. Eng. 2017, 10, 451-469.

97. Labib, A. A decision analysis model for maintenance policy selection using a CMMS. J. Qual. Maint. Eng. 2004, 10, 191-202. [CrossRef]

98. Wang, J.; Liang, Y.; Zheng, Y.; Gao, R.X. An integrated fault diagnosis and prognosis approach for predictive maintenance of wind turbine bearing with limited samples. Renew. Energy 2020, 14, 642-650. [CrossRef]

99. Kaiser, K.A.; Gebraeel, N.Z. Predictive maintenance management using sensor-based degradation models. IEEE Trans. Syst. Man Cybern.-Part A Syst. Hum. 2009, 39, 840-849. [CrossRef]

100. Elwany, A.H.; Gebraeel, N.Z. Sensor-driven prognostic models for equipment replacement and spare parts inventory. Iie Trans. 2008, 40, 629-639. [CrossRef]

101. Sun, J.; Lin, L.; Xi, L. Modified two-stage degradation model for dynamic maintenance threshold calculation considering uncertainty. IEEE Trans. Autom. Sci. Eng. 2011, 9, 209-212. [CrossRef]

102. Nguyen, H.; Do, P.; Vu, H.C. An efficient evolutionary algorithm for joint optimization of maintenance grouping and routing. In Proceedings of the International Conference on Green Technology and Sustainable Development, Ho Chi Minh City, Vietnam, 27-28 November 2020.

103. Zhou, X.; Xi, L.; Lee, J. Reliability-centered predictive maintenance scheduling for a continuously monitored system subject to degradation. Reliab. Eng. Syst. Saf. 2007, 92, 530-534. [CrossRef]

104. You, M.Y.; Li, L.; Meng, G. Cost effective updated sequential predictive maintenance policy for continuously monitored degrading systems. IEEE Trans. Autom. Sci. Eng. 2010, 7, 257-265. [CrossRef]

105. Adjoul, O.; Benfriha, K.; Zant, C.E. Algorithmic strategy for simultaneous optimization of design and maintenance of multicomponent industrial systems. Reliab. Eng. Syst. Saf. 2020, 5, 53-62. [CrossRef]

106. Wakiru, J.; Pintelon, L.; Muchiri, P.N. Integrated remanufacturing, maintenance and spares policies towards life extension of a multi-component system. Reliab. Eng. Syst. Saf. 2021, 215, 107872. [CrossRef]

107. Giri, B.C.; Dohi, T. Quantifying the risk in age and block replacement policies. J. Oper. Res. Soc. 2010, 61, 1151-1158. [CrossRef] 
108. Moakedi, H.; Seyedhosseini, M.S.; Shahanaghi, K. A block-based inspection policy for a multi-component system subject to two failure modes with stochastic dependence. J. Qual. Maint. Eng. 2019, 25, 314-339. [CrossRef]

109. Zequeira, R.; Berenguer, C. Periodic imperfect preventive maintenance with two categories of competing failure modes. Reliab. Eng. Syst. Saf. 2006, 91, 460-468. [CrossRef]

110. Park, M.; Pham, H. A generalized block replacement policy for a k-out-of-n system with respect to threshold number of failed components and risk costs. IEEE Trans. Syst. Man Cybern. Part A Syst. Hum. 2017, 42, 453-463. [CrossRef]

111. Sheu, S.H.; Chen, Y.L.; Chang, C.C.; Zhe, G.Z. A block replacement policy for systems subject to non-homogeneous pure birth shocks. IEEE Trans. Reliab. 2012, 61, 741-748. [CrossRef]

112. Li, M.; Jiang, X.; Negenborn, R.R. Opportunistic maintenance for offshore wind farms with multiple-component age-based preventive dispatch. Ocean. Eng. 2021, 215, 107-116. [CrossRef]

113. Xia, T.; Sun, B.; Chen, Z. Opportunistic maintenance policy integrating leasing profit and capacity balancing for serial-parallel leased systems. Reliab. Eng. Syst. Saf. 2021, 205, 107233. [CrossRef]

114. Nowakowski, T.; Werbinka, S. On problems of multicomponent system maintenance modelling. Int. J. Autom. Comput. 2009, 6, 364-378. [CrossRef]

115. Cai, J.M. Research on Development Platform of Aircraft Maintenance System. Autom. Instrum. 2019, 83, $1029-1037$.

116. Ding, F.; Tian, Z. Opportunistic maintenance for wind farms considering multi-level imperfect maintenance thresholds. Renew. Energy 2012, 45, 175-182. [CrossRef]

117. Koochaki, J.; Bokhorst, J.; Wortmann, H. Condition based maintenance in the context of opportunistic maintenance. Int. J. Prod. Res. 2012, 50, 6918-6929. [CrossRef]

118. Hu, J.; Zhang, L.; Liang, W. Opportunistic predictive maintenance for complex multi-component systems based on DBN HAZOP model. Process Saf. Environ. Prot. 2012, 90, 376-388. [CrossRef]

119. Hou, W.; Jiang, Z. An opportunistic maintenance policy of multi-unit series production system with consideration of imperfect maintenance. Appl. Math. Inf. Sci. 2013, 7, 283-290. [CrossRef]

120. Liang, Z.; Parlikad, A.K. Predictive group maintenance for multi-system multi-component networks. Reliab. Eng. Syst. Saf. 2020, 13, 14-25. [CrossRef]

121. Ding, S.H.; Kamaruddin, S. Assessment of distance-based multi-attribute group decision-making methods from a maintenance strategy perspective. J. Ind. Eng. Int. 2015, 11, 73-85. [CrossRef]

122. Hadjidemetriou, G.M.; Herrera, M.; Parlikad, A.K. Predictive group maintenance for networks of bridges, based on condition and criticality analysi. In Proceedings of the 23rd Euro Working Group on Transportation, Paphos, Cyprus, 18-20 September 2020.

123. Fan, D.; Zhang, A.; Feng, Q. Group maintenance optimization of subsea Xmas trees with stochastic dependency. Reliab. Eng. Syst. Saf. 2021, 209, 107-120. [CrossRef]

124. Visser, J.K.; Jordaan, J. A maintenance strategy model for static equipment using inspection methodologies and risk management. S. Afr. J. Ind. Eng. 2009, 20, 83-94. [CrossRef]

125. Tsai, W.H.; Yang, C.H.; Chang, J.C. An activity-based costing decision model for life cycle assessment in green building projects. Eur. J. Oper. Res. 2014, 238, 607-619. [CrossRef]

126. Chen, Y.; Feng, H. Maintenance strategy of multicomponent system based on structure updating and group importance measure. Commun. Stat.-Theory Methods 2020, 42, 1-17. [CrossRef]

127. Ghasemi, A.; Esameili, S. Optimal condition-based maintenance replacement based on logical analysis of data. Lect. Notes Eng. Comput. Sci. 2013, 1, 830-833.

128. Hai, V.; Do, P.; Barros, A. Maintenance grouping strategy for multi-component systems with dynamic contexts. Reliab. Eng. Syst. Saf. 2014, 132, 233-249.

129. Yang, Y.; Li, F.; Hou, C.Y.; Yang, Y.; Li, F.; Hou, C.Y. Correlation based multi-component system opportunity group maintenance optimization. Comput. Integr. Manuf. Syst. 2012, 18, 827-832.

130. Chen, Y.M.; Li, S.B.; Jin, B. Determination of cycle of mitering lock overhaul based on preventive group maintenance strategy. J. Southeast Univ. 2014, 44, 436-440.

131. Cai, J.; Li, X.; Xiao, L.C. Optimization model of group maintenance scheme for civil aircraft. Nanjing Univ. Sci. Technol. 2015, 39, 306-311.

132. Aizpurua, J.I.; Catterson, V.M.; Papadopoulos, Y. Supporting group maintenance through prognostics-enhanced dynamic dependability prediction. Reliab. Eng. Syst. Saf. 2017, 16, 171-188. [CrossRef]

133. Horenbeek, A.V.; Pintelon, L. A dynamic predictive maintenance policy for complex multi-component systems. Reliab. Eng. Syst. Saf. 2013, 120, 39-50. [CrossRef]

134. Bouvard, K.; Artus, S.; Berenguer, C. Condition-based dynamic maintenance operations planning and grouping. Application to commercial heavy vehicles. Reliab. Eng. Syst. Saf. 2011, 96, 601-610. [CrossRef]

135. Cadi, A.; Gharbi, A.; Dhouib, K. Integrated production, maintenance and quality control policy for unreliable manufacturing systems under dynamic inspection. Int. J. Prod. Econ. 2021, 236, 108-120.

136. Kristjanpoller, F. Opportunistic Strategy for Maintenance Interventions Planning: A Case Study in a Wastewater Treatment Plant. Appl. Sci. 2021, 23, 11-21.

137. Marutani, J.; Ohtsuka, T. A Real-Time Algorithm for Nonlinear Infinite Horizon Optimal Control by Time Axis Transformation Method. Int. J. Robust Nonlinear Control. 2013, 23, 1955-1971. [CrossRef] 
138. Do, P.; Hai, C.V.; Barros, A. Maintenance grouping for multi-component systems with availability constraints and limited maintenance teams. Reliab. Eng. Syst. Saf. 2015, 14, 56-67. [CrossRef]

139. Wildeman, R.E.; Dekker, R.; Smit, A.C.J.M. A dynamic policy for grouping maintenance activities. Eur. J. Oper. Res. 1997, 99, 530-551. [CrossRef]

140. Chal, N.; Dahane, M.; Beldjilali, B. Optimisation of preventive maintenance grouping strategy for multi-component series systems: Particle swarm based approach. Comput. Ind. Eng. 2016, 10, 440-451.

141. Vijaya, N.V.; Chaturvedi, S.K. Multi-component maintenance grouping optimization based on stochastic dependency. J. Risk Reliab. 2021, 235, 56-62.

142. Doostparast, M.; Kolahan, F.; Doostparast, M. Optimisation of PM scheduling for multi-component systems-A simulated annealing approach. Int. J. Syst. Sci. 2015, 7, 1199-1207. [CrossRef]

143. Barron, Y. Group maintenance policies for an R-out-of-N system with phase-type distribution. Ann. Oper. Res. 2018, 261, 79-105. [CrossRef]

144. Tian, Z.; Liao, H. Condition based maintenance optimization for multi-component systems using proportional hazards model. Reliab. Eng. Syst. Saf. 2011, 96, 581-589. [CrossRef]

145. Wang, H. A survey of maintenance policies of deteriorating systems. Eur. J. Oper. Res. 2002, 139, 469-489. [CrossRef]

146. David, W.; Enrico, Z. The evolution of system reliability optimization. Reliab. Eng. Syst. Saf. 2019, 192, 106259.

147. Albakkoush, S.; Pagone, E.; Salonitis, K. Scheduling Challenges within Maintenance Repair and Overhaul Operations in the Civil Aviation Sector. In Proceedings of the TESConf 2020-9th International Conference on Through-life Engineering Services, Cranfield, UK, 3-4 November 2020.

148. Ritter, O.; Wende, G.; Gentile, R. Intelligent Diagnostics for Aircraft Hydraulic Equipment. In Proceedings of the European Conference of the Prognostics and Health Management Society, Utrecht, The Netherlands, 3-6 July 2018.

149. Goebel, K.; Hai, Q.; Eklund, N. Modeling Propagation of Gas Path Damage. In Proceedings of the Aerospace Conference, Big Sky, MT, USA, 3-10 March 2007; pp. 1-8.

150. Saxena, A.; Kai, G.; Simon, D. Damage propagation modeling for aircraft engine run-to-failure simulation. In Proceedings of the 2008 International Conference on Prognostics and Health Management, Denver, CO, USA, 6-9 October 2008; pp. 1-6.

151. Chiachio, J.; Chiachio, M.; Saxena, A. An Energy-Based Prognostic Framework to Predict Fatigue Damage Evolution in Composites. In Proceedings of the Annual Conference of the Prognostics and Health Management Society, New Orleans, LA, USA, 25-27 October 2013.

152. Corbetta, M.; Sbarufatti, C.; Manes, A. Real-Time Prognosis of Crack Growth Evolution Using Sequential Monte Carlo Methods and Statistical Model Parameters. IEEE Trans. Reliab. 2015, 64, 736-753. [CrossRef]

153. Meissner, R.; Rahn, A.; Kai, W. Developing prescriptive maintenance strategies in the aviation industry based on a discrete-event simulation framework for post-prognostics decision making. Reliab. Eng. Syst. Saf. 2021, 214, 107812. [CrossRef]

154. Ahn, C.K.; Kar, H. Expected Power Bound for Two-Dimensional Digital Filters in the Fornasini-Marchesini Local State-Space Model. IEEE Signal Processing Lett. 2015, 22, 1065-1069. [CrossRef]

155. Sun, C.; Lin, Y.; Han, M. Stability and Hopf bifurcation for an epidemic disease model with delay. Chaos Solitons Fractals 2006, 30, 204-216. [CrossRef]

156. Guerineau, L.; Gouno, E. Inference for a Failure Counting Process Partially Observed. IEEE Trans. Reliab. 2015, 64, 311-319. [CrossRef]

157. Ruiz, M.; Ramirez, L.; Navarrina, F. A Mathematical Model to Evaluate the Impact of the Maintenance Strategy on the Service Life of Flexible Pavements. Math. Probl. Eng. 2019, 3, 9480675. [CrossRef]

158. Yuan, F.Q.; Lu, J.M.; Batalden, B.M. The investigation of physical explanation for proportional hazard model (PHM) for typical failure mechanisms. Reliab. Maintainab. Symp. 2017, 2, 1-6.

159. Prakash, G.; Narasimhan, S.; Pandey, M. Condition Based Maintenance of Low Speed Rolling Element Bearings using Hidden Markov Model. Int. J. Progn. Health Manag. 2020, 8, 16-22. [CrossRef]

160. Khalouli, S.; Benmansour, R.; Hanafi, S. An ant colony algorithm based on opportunities for scheduling the preventive railway maintenance. In Proceedings of the International Conference on Control, Saint Julian's, Malta, 6-8 April 2016; pp. 594-599.

161. Shang, H. Maintenance Modelling, Simulation and Performance Assessment for Railway Asset Management. Ph.D. Thesis, Université de Technologie de Troyes, Troyes, France, 2015.

162. Ricketts, N. Railway Bridge Maintenance | Preventive Maintenance; ICE Publishing: London, UK, 2017. [CrossRef]

163. Pour, S.M.; Stidsen, T.; Rasmussen, K.M. The Preventive Signaling Maintenance Crew Scheduling Problem for European Railway Traffic Management System (ERTMS); DTU Management Engineering: Roskilde, Denmark, 2015.

164. Cheng, H.; Cao, Y.; Wang, J. A preventive, opportunistic maintenance strategy for the catenary system of high-speed railways based on reliability. Inst. Mech. Eng. Part F J. Rail Rapid Transit 2019, 234, 095440971988421. [CrossRef]

165. Okamura, Y.; Nagatomo, T. Maintenance technologies with sensors for bogies of railway vehicles. J. Jpn. Soc. Tribol. 2017, $52,23-29$.

166. Zhang, C.; Duan, Y.; Depot, B.E. Research on Maintenance Standard for CRH3C EMU Faiveley Pantograph of Beijing-Tianjin Inter-city Railway. High Speed Railw. Technol. 2016, 7, 58-60.

167. Guo, L.Y.; Hong, S.S. Optimization of maintenance strategy for high-speed railway catenary system based on multistate model. J. Meas. Sci. Instrum. 2019, 10, 348-360. 
168. Xu, R.H.; Lai, Y.C.; Huang, K.L. Decision support models for annual catenary maintenance task identification and assignment. Transp. Res. Part E Logist. Transp. Rev. 2021, 152, 102402. [CrossRef]

169. Yu, G. Research on Maintenance Strategy Optimization Model of Pumped-Storage Power Unit Based on Devices Failure Probability Distribution. Water Power 2016, 42, 83-86.

170. Pargar, F. A New Mathematical Model for Scheduling Preventive Maintenance and Renewal Projects of Multi-Unit Systems; Application to Railway Track; University of Twente: Enschede, Netherlands, 2015; Volume 13, pp. 15-19.

171. Lin, B.; Wu, J.; Lin, R. Optimization of high-level preventive maintenance scheduling for high-speed trains. Reliab. Eng. Syst. Saf. 2019, 183, 261-275. [CrossRef]

172. Kucukoglu, I.; Ozturk, N. An advanced hybrid meta-heuristic algorithm for the vehicle routing problem with backhauls and time windows. Comput. Ind. Eng. 2015, 86, 60-68. [CrossRef]

173. Fan, W.; Machemehl, R.B. Optimal Transit Route Network Design Problem with Variable Transit Demand: Genetic Algorithm Approach. J. Transp. Eng. 2015, 132, 40-51. [CrossRef]

174. Tang, D.; Gupta, G. An efficient parallel dynamic programming algorithm. Comput. Math. Appl. 2015, 30, 65-74. [CrossRef]

175. Jia, Q.M.; Xiao, H. An Approach to Track Maintenance Prioritization for Urban Rail Transit. Public Work. Manag. Policy Res. Pract. Transp. Infrastruct. Environ. 2015, 20, 159-175.

176. Ming, Z. Decision approach of maintenance for urban rail transit based on equipment supervision data mining. In Proceedings of the IEEE International Conference on Intelligent Data Acquisition \& Advanced Computing Systems: Technology \& Applications, Warsaw, Poland, 24-26 September 2015; pp. 376-380.

177. Li, W. Reflections on the Urban Rail Transit Vehicle Maintenance Resource Sharing. Sci. Technol. Inf. 2014, 12, $194-195$.

178. Hu, E.H.; Gao, M.Z.; Zhu, C.R. Study of Fault Diagnosis and Pre-alarm Method for ZDJ-9 Switch Equipment in Urban Rail Transit. Railw. Signal. Commun. 2016, 52, 71-73.

179. Jie, G.; Cong, L.; Wu, Y. Design and Implementation of Equipment Operation and Maintenance Management System for Urban Rail Transit. Urban Rapid Rail Transit 2015, 28, 78-80.

180. Bi, X.; Hong, C.; Lai, H. Classification and Coding for Urban Rail Transit Facility Equipment Based on BIM. Urban Mass Transit 2016, 19, 5-9.

181. Rauwolf, G.A.; Coverstone, C.V.L. Near-optimal low-thrust orbit transfers generated by a genetic algorithm. J. Spacecr. Rocket. 2015, 33, 859-862. [CrossRef]

182. Yu, H.; Yin, T.; Sun, C. An adaptive model selection strategy for surrogate-assisted particle swarm optimization algorithm. In Proceedings of the Computational Intelligence, Wuxi, China, 16-19 December 2016; pp. 1-8.

183. Byon, E.; Lewis, N.; Yu, D. Optimal maintenance strategies for wind turbine systems under stochastic weather conditions. IEEE Trans. Reliab. 2010, 59, 393-404. [CrossRef]

184. Tan, Y. On the promotion strategy of power equipment maintenance. Priv. Technol. 2018, 11, 13.

185. Aseel, A.; Mezhera, A. Determining the Efficiency of Maintenance Programs Using Performance Indicators: Case Study in Electric Cables and Wires Factory. Int. J. Innov. Creat. Change 2020, 11, 16-22.

186. Sitinor, A. Forensic of Solar PV: A Review of Potential Faults and Maintenance Strategies. In Proceedings of the International Conference on Engineering and Emerging Technologies, Istanbul, Turkey, 27-28 October 2021.

187. Zhang, Z.; Zhao, J. A deep belief network based fault diagnosis model for complex chemical processes. Comput. Chem. Eng. 2017, 107, 395-407. [CrossRef]

188. Aghaee, A.; Aghaee, M.; Fathi, M.R. A novel fuzzy hybrid multi-criteria decision-making approach for evaluating maintenance strategies in petrochemical industry. J. Qual. Maint. Eng. 2020, 27, 52-58. [CrossRef]

189. Bakir, I.; Yildirim, M.; Ursavas, E. An Integrated Optimization Framework for Multi-Component Predictive Analytics in Wind Farm Operations \& Maintenance. Renew. Sustain. Energy Rev. 2021, 138, 110639.

190. Yildirim, M.; Xu, A.S.; Nagi, Z.G. Sensor-driven condition-based generator maintenance scheduling-Part I: Maintenance problem. IEEE Trans. Power Syst. 2016, 31, 4253-4262. [CrossRef]

191. Shayesteh, E.; Yu, J.; Hilber, P. Maintenance optimization of power systems with renewable energy sources integrated. Energy 2018, 149, 577-586. [CrossRef]

192. Benedetti, M.D.; Leonardi, F.; Messina, F. Anomaly Detection and Predictive Maintenance for photovoltaic Systems. Neurocomputing 2018, 310, 59-68. [CrossRef]

193. Wang, P.; Wang, S. Analysis on operation and maintenance strategy of power transmission line. Decis. Explor. $2018,11,60$.

194. Liu, R. Analysis on management and maintenance strategy of high voltage line. China's New Technol. Prod. 2018, 20, 134-135.

195. Zcan, E.; Yumuak, R.; Eren, T. A novel approach to optimize the maintenance strategies: A case in the hydroelectric power plant. Eksploat. I Niezawodn.-Maint. Reliab. 2021, 23, 324-337. 